\title{
First Total Posterior Craniopagus Twins in Central African Republic: Two Years Challenge of Management
}

\section{Gody Jean Chrysostome ${ }^{1 *}$, Bogning Mejiozem Brice Olivier ${ }^{1}$, Houndjahoue Ghislain Franck ${ }^{1}$, Pasotti Ombretta ${ }^{2}$, Enoc Mariella², Carlo Efisio Marras ${ }^{3}$}

${ }^{1}$ Centre Hospitalier Universitaire Pédiatrique de Bangui, Bangui, Central African Republic

${ }^{2}$ Hôpital Pédiatrique Bambino Gesu de Rome, Rome, Italy

${ }^{3}$ Département de Neurochirurgie de l'Hôpital Pédiatrique Bambino Gesu de Rome, Rome, Italy

Email: *jcgody@hotmail.com

How to cite this paper: Chrysostome, G.J., Olivier, B.M.B., Franck, H.G., Ombretta, P., Mariella, E. and Marras, C.E. (2021) First Total Posterior Craniopagus Twins in Central African Republic: Two Years Challenge of Management. Open Journal of Pediatrics, 11, 438-449.

https://doi.org/10.4236/ojped.2021.113041

Received: August 6, 2021

Accepted: September 10, 2021

Published: September 13, 2021

Copyright $\odot 2021$ by author(s) and Scientific Research Publishing Inc. This work is licensed under the Creative Commons Attribution International License (CC BY 4.0).

http://creativecommons.org/licenses/by/4.0/

\begin{abstract}
Introduction: Countries with limited resources have real difficulties in separating craniopagus twins. Separation surgery cannot be considered there due to lack of technological conditions and appropriate means. Objective: To show the benefits of an Italian-Central African humanitarian collaboration, after two years follow-up, aiming to improve the first childhood years of craniopagus twins, born in the Central African Republic and separated in Rome. Case Report: The two female conjoined craniopagus twin, born at term on June 29, 2018 in Mbata located about $96 \mathrm{~km}$ from Bangui (CAR), were referred to the neonatology unit of the CHUPB on their $3^{\text {rd }}$ day of life. The mother was 31-year-old, gravida 4 and para 5. Prenatal cares were quantitatively and qualitatively poorly followed. The diagnosis of posterior conjoined craniopagus twins associated with early neonatal infection was retained. After seven days of antibiotics and regression of infectious symptoms, the newborns were kept in the neonatology unit for a closer follow-up, pending the completion of administrative procedures for a medical evacuation as part of the international humanitarian activities of the Pediatric Hospital of the Holy Seat in collaboration with the Pediatric Teaching Hospital in Bangui. Finally, the twins were transferred to the Bambino Gesu Hospital in Rome on September 10, 2018 where the 3D images confirmed the total posterior fusion. Between May 2019 and June 2020 thirty hours of interventions allowed a step-by-step separation of the twins, with a gradual rerouting of the shared blood supply, remodeling and re-creating a skin to cover the skull bones. No postoperative complications were recorded; the twins recovered satisfactorily after 6 months of separation and are awaiting discharge at their origin country where the CHUPB team will continue monitoring. Conclusion: The suc-
\end{abstract}


cessful separation of total posterior craniopagus twins remains historically scarce and the guarantee of success has been based on detailed and well planned surgical management.

\section{Keywords}

Craniopagus Twins, Collaboration, Pediatrics, Neurosurgery, CHUPB, Bambino Gesu Hospital in Rome

\section{Introduction}

Head conjoined craniopagus twins are rare. The malformation occurs in one of every 2.5 million births and represents $2 \%$ to $6 \%$ of conjoined twins [1] [2] [3]. It appears during monozygous monoamniotic twin pregnancies which represent $1 \%$ of twin pregnancies. The abnormality is due to the incomplete division of the embryonic disc beyond the 13th gestational day leading to conjoined twins [4] [5].

Diagnosis is possible as early as 8 weeks of gestation, but precise evaluation of common structures is not possible [6] [7]. Ultrasound at 12 weeks of gestation allows clinicians to assess viability and, in the case of non-viability, to suggest early medical abortion; preventing thus hysterotomy in the case of delayed interruption [6] [8] [9]. For viable cases, the management is a challenge, even for well experienced teams. Many parents decide to abort due to the prognosis and the quality of life issues the twins are expected to face [6] [7]. In addition, the probability of a successful separation may vary [7] [10]. So, many challenges are to be taken up in countries like Central African Republic, which have long been negatively affected by military conflicts. In countries such as Central African Republic, surprise often occurs during childbirth; as prenatal diagnosis is not done with the use of relatively low health services and often qualitatively poor follow-up. This reality reveals the problem of the practitioner's anxiety the developing countries face to the lack of solutions and the resignation of the patient's surrounding abandoned to their sad fate, while the solution exists in developed countries. In this specific case, exchanges based on a fair ethical consideration made it possible to push back the limits of this problem and to overcome the inequality of opportunities mentioned in the first 1000 days after birth. These twins were thus given the opportunity to be on the ideal developmental pathway for future adulthood. The current report, focusing on abnormalities in infantile period which may affect in the long term the development of the future adult, aims to describe the interventions preceding the correction of the abnormalities and to show the type of collaboration likely to remove the financial barriers preventing the access to quality care in developing countries.

\section{Case Report}

Ervina and Prefina were twins born at term on June 29, 2018 in Mbata in the 
Lobaye prefecture located about $96 \mathrm{~km}$ from Bangui, the capital of Central African Republic. The twins were transferred from the Mbata maternity hospital on July 2, 2018 to the neonatology unit in Bangui Pediatric Teaching Hospital, for their conjoined skulls. The parents were poor. The mother was 31, gravida 4 and para 5, without consanguinity with her 35-year-old husband. Prenatal consultations were quantitatively and qualitatively poorly followed. No ultrasound examination was therefore performed. The date of the last period was not known. The delivery marked by a failure to engage resulted in a cesarean section with the extraction of two twins weighing 4200 grams together, with an Apgar score of 8/10 for the first one (Ervina) and 9/10 for the second (Prefina). The anamnestic proofs allowed us to assess a neonatal infectious score of 3, which represents a major infectious risk. The clinical examination on admission had noted a poor general impression; the temperature was $38.3^{\circ} \mathrm{C}$ for both twins with a more exacerbated regular tachycardia in Prefina. The dysmorphological examination revealed two conjoined sisters tucked nape to nape. They had in common the entire occipito-temporal area as well as the cranial bones and the skin of the same area (Figure 1). Archaic reflexes were blunted. Elsewhere, there was no other associated dysmorphia. Laboratory investigation revealed hematological parameters within normal ranges and an increase in $\mathrm{C}$ reactive protein (CRP) on day 1 in twins; with lower hemoglobin and platelets in Prefina and higher white blood cells in Ervina. All blood investigations became normal on day 4 (Table 1).

Ultrasound and cranial X-ray done in Bangui had shown a common occipital bone. The twins were diagnosed as posterior craniopagus conjoined twins associated with early neonatal infection.

The protocol therapeutic consisting of antibiotics (injectable cefotaxime, injectable ampicillin, injectable gentalline), fluid therapy associated with a naso-gastric tube milk feeding. Considering the inadequacy of the technical platform in Bangui, the decision of multidisciplinary team was to transfer the twins

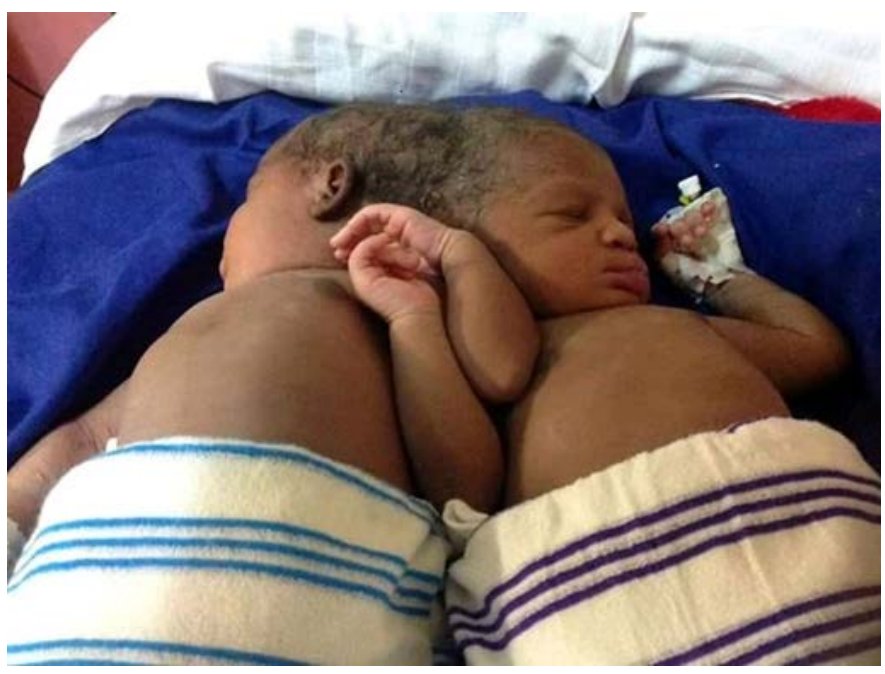

Figure 1. Craniopagus twins features at birth. 
Table 1. Hemogram and CRP results at day 1 and day 4 of hospitalization.

\begin{tabular}{ccccc}
\hline \multirow{2}{*}{ Paramètres } & \multicolumn{3}{c}{ Prefina } & \multicolumn{3}{c}{ Ervina } \\
\cline { 2 - 5 } & $\mathrm{J} 1$ & $\mathrm{~J} 4$ & $\mathrm{~J} 1$ & $\mathrm{~J} 4$ \\
\hline $\mathrm{RBC}\left(10^{9} / \mathrm{l}\right)$ & 6 & 5 & 4.5 & 4.8 \\
$\mathrm{Hb}(\mathrm{g} / \mathrm{dl})$ & 13 & 17 & 18 & 18 \\
MCV $\left(\right.$ micron $\left.^{3}\right)$ & 110 & 100 & 120 & 115 \\
Reticulocyte $\left(10^{9} / \mathrm{l}\right)$ & 240 & 70 & 230 & 140 \\
WBC $\left(10^{9} / \mathrm{l}\right)$ & 10 & 13 & 30 & 12 \\
Neutrophile $\left(10^{9} / \mathrm{l}\right)$ & 8 & 6 & 10 & 7 \\
Lymphocyte $\left(10^{9} / \mathrm{l}\right)$ & 5 & 5 & 6 & 4 \\
Platelets $\left(10^{9} / \mathrm{l}\right)$ & 150 & 200 & 200 & 250 \\
CRP & 44 & 3 & 36 & 2 \\
\hline
\end{tabular}

RBC: Red blood cells; Hb: Hemoglobin; MCV: Mean corpuscular volume; WBC: White blood cells.

as soon as possible to a team which is able to perform the separation.

The evolution was marked by the regression of infectious symptoms on the seventh day of the antibiotic, and the twins were kept in the neonatology unit for a closer follow-up pending the completion of administrative procedures for a sanitary evacuation. During this period our team provided advice on mother's diet, personal hygiene and the role of the father. As part of the international humanitarian activities of the Pediatric Hospital of Holy Seat, in collaboration with Bangui Pediatric Teaching Hospital, the conjoined twins were transferred to Bambino Gesu Hospital in Rome on September 10, 2018.

Three-D imaging done in Italy highlighted a common occipital bone and in depth the two sisters were sharing the sickle, the tentorium as well as a large part of the venous system.

The first clinical and para-clinical report from Rome, confirmed that the twins are in general good condition, the neurological and clinical parameters are normal. However, there was a difference in blood pressure, with cardiac hyper-output in Ervina. Many psychological features were in common, except the personality, different and distinct: Prefina playful and lively whereas Ervina looks more serious and attentive.

The diagnosis of total posterior craniopagus will be retained (Figure 2) and the sisters transferred to the neurorehabilitation unit, then to the neurosurgery department in order to study the separation procedures (Figure 3). The preparation of the craniopagus for separation consisted of neuroreeducation interventions targeting a level of cognitive and motor development corresponding to their age. Maintaining in the best possible posture and optimizing the visual relationship using a mirror system have been performed.

The ethics committee was involved in the procedure. They required giving to the two little girls the same chances of quality of life. In addition, this complex case will be presented and discussed during the first world conference about twins' conjoined surgery in February 2019 in New Delhi (India) [11]. 


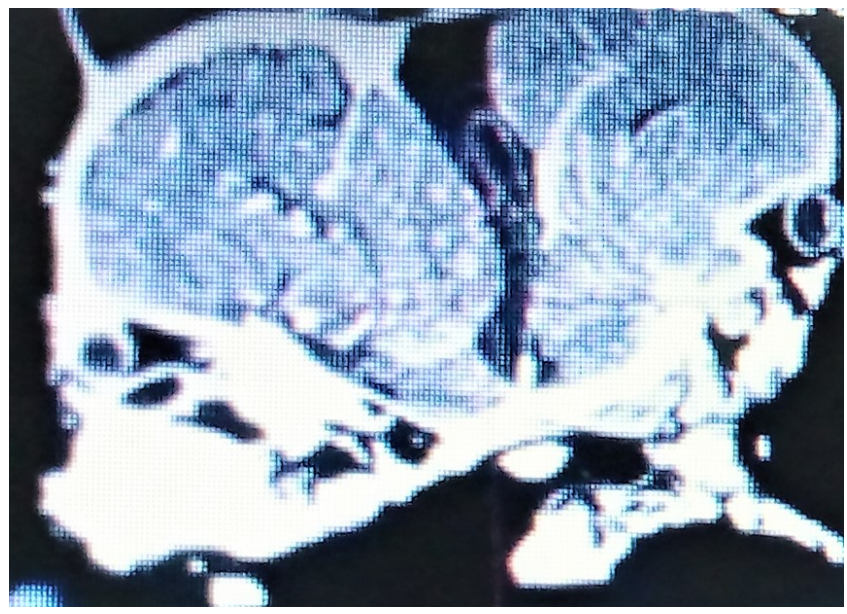

Figure 2. Morphologic aspect of the fusion in 3-D imaging.

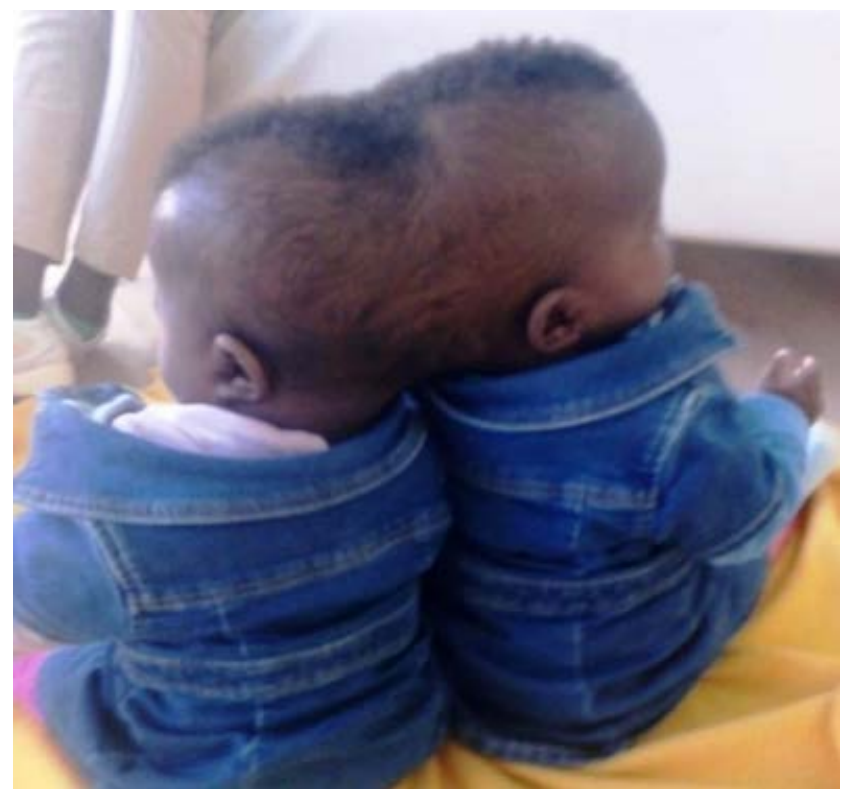

Figure 3. Total posterior craniopagus twins aspect at 1-year-old.

At the end of this process, Bambino Gesù's neurosurgery team decided to apply a three-step separation in order to gradually reconstruct two independent venous systems. The multidisciplinary team was made up of more than 30 members: neurosurgeons, anesthesiologists, neuroradiologists, plastic surgeons, neuro-educators, engineers, nurses of various specialties and physiotherapists [11].

In May 2019, during the first surgery, the neurosurgeons had separated part of the tent and the first of the two common transverse sinuses. These structures, covered by a membrane made of biocompatible materials, have been assigned to each of the twins and until the last step [11].

The second surgery took place in June 2019. The team, assisted by the group of anesthesiologists, had separated the upper sagittal sinuses and the junction point of the cerebral venous sinus using a neuronavigator; given the narrow op- 
erating space. One year after the second surgery (June 5, 2020), final separation took place (Figure 4(a) and Figure 4(b)) while the reconstructed venous structures have consolidated with great functionality. In addition, the subcutaneous "expanders" positioned a few months earlier made it possible to obtain a sufficient portion of skin to cover the skull of each of the twins after separation. The surgery procedure began with the removal of the skin "expanders", then the separation of the second transverse sinus and its tentorium; finally, the skull separation was performed. After the twins were separated, the reconstruction of the brain envelope, the remodeling of the skull's bone and its covering with the skin lining were carried out with two teams in two separate rooms.

No abnormalities were noted at the end of the interventions; the hemodynamic status being stable with normal psychomotor skill according to the postoperative findings of neuroscience specialists in charge of the twins.
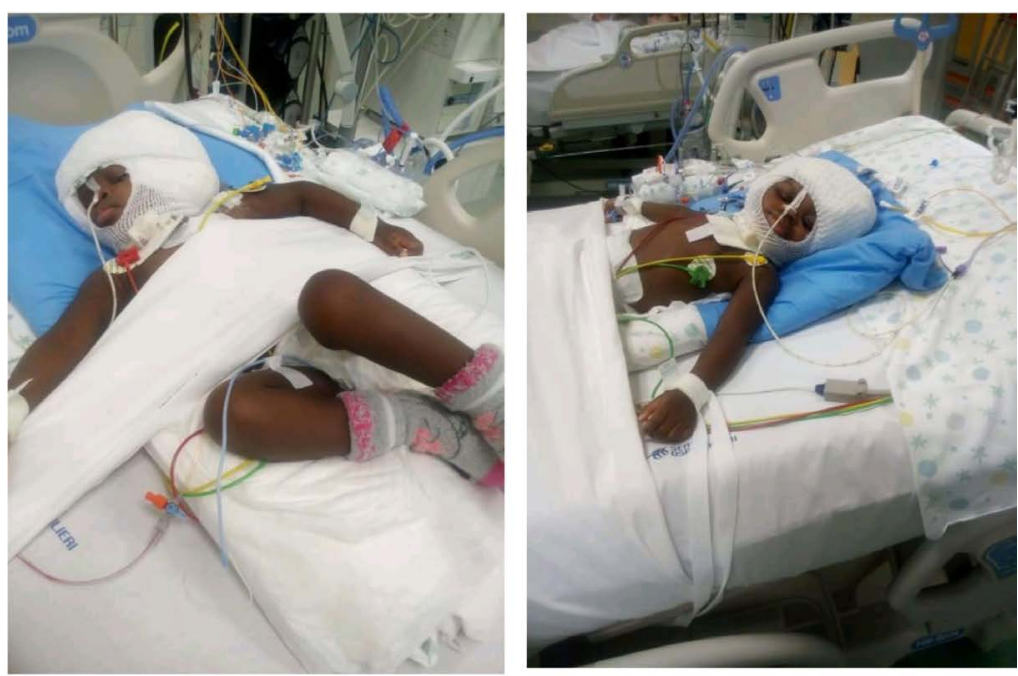

(a)
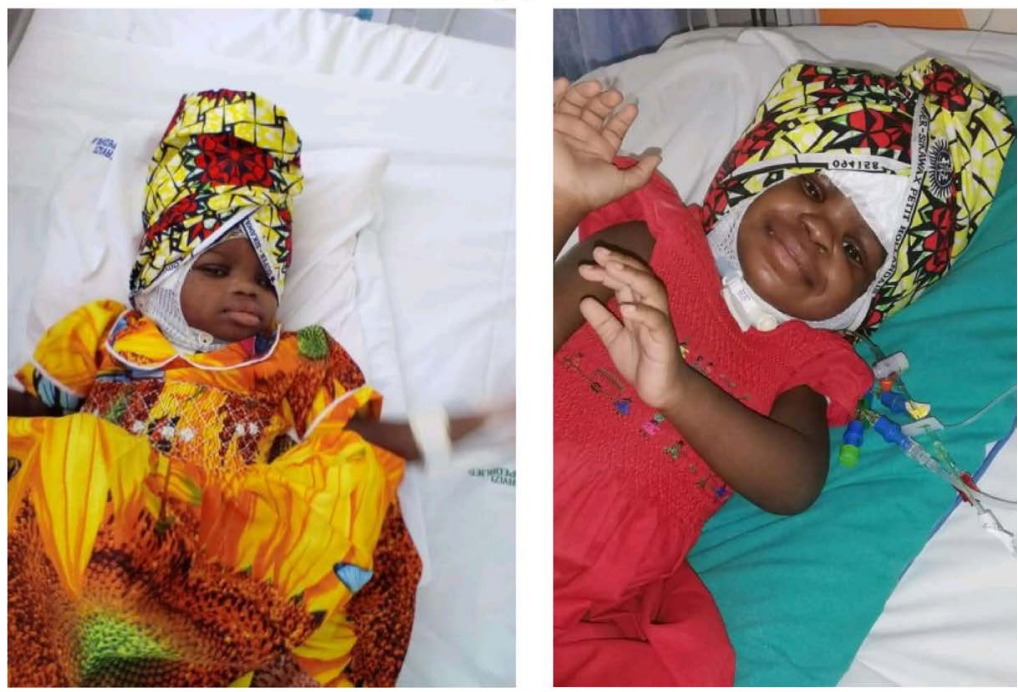

(b)

Figure 4. (a) Twins pictures after separation; (b) Picture post bone remodeling. 


\section{Discussion}

\subsection{Regarding the Malformation}

1) Epidemiologically, conjoined twins represent one of the rarest forms of congenital anomalies described in approximately $0.2 / 10,000$ pregnancies, but only $0.05 / 10,000$ live births [12]. Craniopagus are a rare malformation that occurred once in 2.5 million births and represent only $2 \%$ to $6 \%$ of conjoined twins [1] [2] [3] [6] [12]. In Central African Republic, there are no epidemiological data on conjoined twins. About gender, a greater incidence of female twins is observed in $70 \%$ to $75 \%$ of cases [8] [9] [13] [14]; thus corroborating our observation.

2) Regarding the mechanism of occurrence, the hypothesis of late incomplete splitting of a common embryonic mass is the most widely recognized. It would involve a disorder at the molecular level disrupting cell adhesion or even apoptosis at an early stage of embryogenesis [15]. The secondary union of two initially separate mono-ovular embryonic discs-which can be done at the level of a body region in a symmetrical way (symmetrical conjoined twins) or asymmetric (ectoparasitic or endoparasitic twins) - constitutes the hypothesis more and more mentioned [16] [17]. Also, placentation in twin pregnancies depends on the stage of embryonic division. If cell differentiation takes place after the 14th day of embryonic development, incomplete developmental delay results in conjoined twins [18] [19]. In general, there are no karyotypic abnormalities, and race, inheritance, birth order or inbreeding does not influence the process of onset [19].

3) About classifications, several have been anatomically identified, according to the site of union, common organs and symmetry. Saint-Hilaire established one in 1832, based on the description of the external union site and on symmetry. Ventral unions occur in $87 \%$ and are classified into cephalopagus (11\%), thoracopagus (19\%), omphalopagus (18\%), ischiopagus (11\%), and parapagus (28\%). Dorsal unions occur in $13 \%$ of conjoined twins and are classified into craniopagus (5\%), rachipagus (2\%) and pygopagus (6\%) [1] [6] [20] [21].

Another classification takes into account the body site, divided into anterior or thoracopagus, posterior or pygopagus, cephalic or craniopagus and caudal or ischiopagus [22]. Considering ultrasound, Duhamel classification established in 1966 seems the most appropriate; making a synthesis of the different classifications taking into account the data of embryogenesis. It differentiates the cephalopagus twins with parallel axes and which are "side by side", from the quadrupagus which are "face to face" and the crucipagus with opposite axes which are close to the omphalopagus [5] [20] [22]. From a prognostic and therapeutic point of view, Afzal [23] distinguishes among conjoined twins: those who cannot survive in utero or those who are born and die during infancy from those who survive beyond infancy with or without the possibility of being surgically separated. From this point of view, the third difficulty linked to the separation of Abidjan twins, described by Konan Blé in 2008 [10] remains for now an inso- 
luble reality for most of the developing countries.

4) Regarding the diagnosis and management of the couple mother/child, the antenatal diagnosis is based on ultrasound between 12 and 14 weeks of amenorrhea (WA) [24] [25] [26]. Some incomplete forms can be difficult to diagnose. An ultrasound performed at $22 \mathrm{WA}$ makes it possible to elucidate these forms, to identify the area of attachment more precisely, to analyze the duplicated structures and to look for the associated malformations, mainly cardiac anomalies [6] [9] [22]. Konan cited in his report the other useful tests for diagnosis and management. These are ultrasound, nuclear magnetic resonance imaging, uterine contents and karyotype [10]. The ultrasound has been performed in Abidjan on the day of delivery at 37 weeks of amenorrhea. The CT angioscan has been performed in Abidjan twins on the 15th day of life; revealing the brain state and common structures. In Central African Republic, no exploration has been done: in the absence of ultrasound in the location where the twins were born and in the postnatal period for unavailability of imaging techniques adapted to the pathology. In addition, if these explorations can provide additional information for prognostic purposes [6] [24], everything in low-resource countries suggests a random outcome of the birth of conjoined twins and their future. In Ivory Coast as in Central African Republic, deliveries take place by caesarean section with craniopagus twins whose life pathway will be different. Those of Abidjan, kept alive in an obstetric emergency context by a medico-social team who then had to improvise postnatal care without the support of parents negatively influenced by their culture, experienced the succession of various pathologies: nosocomial infection, bedsores, anemia leading to death at four and half months of life [10]. Those of Mbata, kept alive with the help of their parents, ended up being separated thanks to the successful transfer procedures. It was not the case in Abidjan [10]. In Bangui, while waiting for the transfer, the difficulties related to the positioning of newborns at the breast, the physical particularity of the babies and the loads inherent in their growing were taken into account by our team. Thus, it was agreed to keep the mother, the father and the newborns in a dedicated space in the hospital to allow the nursery nurses to provide the necessary support for the exclusive breastfeeding simultaneously to the twins via naso-gastrique tube after expressing the milk by the mother. During the trip by a regular flight, the mother is assisted by a nursery nurse and the commercial formula is given simultaneously to the twins using bottles.

This observation leads us to discuss the strategic issues related to assessment, ethics and internal and external collaboration that should lead to the transfer of twins where the care is adequate.

5) Regarding evaluation and ethics, Konan observed in his report in 2008: if the neurosurgery separation was technically possible by sacrificing one of the twins, the conditions for its implementation on site were not met: postoperative intensive care unit poorly adapted, uncertain financial support, poorly adapted postoperative resuscitation service, uncertain financial support, and the fact that 
such an intervention had ever been performed in our institution. Al Rabeeah noted, from the review of cases of conjoined twins on several continents, that it is a heavy surgery, very expensive, which poses ethical problems in front of the necessity of sacrificing a child to the detriment of the other [25]. Fortunately, the success of Voris in 1955 in Chicago having obtained the long-term survival of the partial craniopagus twins, one being normal, the other severely impaired and the many advances in medicine including brain imaging, neuro-techniques, anesthesia and neurosurgery have mitigated the idea of sacrificing one of the twins [1] [27] [28] [29].

Therefore, separation surgery for the two twins can begin. Unless there is no severe malformation associated. Few teams have the operative expertise of craniopagus twins, with a risk of perioperative death of 50\% [30]. In our case, the problem is not limited to the choice between two twins; since we were in doubt about the vulnerability of one or the other in the absence of suitable exploration tools. We had to manage at the same time the possible associated pathologies hidden with regard to our medical density, the bodily phenotype of the twins with its impact, the psychosocial environment and the request for reparation expressed by the parents. We had to wait for the arrival of the conjoined twins in Rome to discover, as mentioned above, the difference in blood pressure with cardiac hyper-output in one of the twins. These facts suggest that without the transfer, we would have managed hemodynamic complications in one of the twins and possibly end up in one of the situations where one of the twins might deteriorate [31].

\subsection{Regarding Intra and External Collaboration}

For adequate care, our medical evacuation committee-aware of the limits of socio-health human resources against the needs of the ideal development of future adults [32] — was going to do everything so that the economic environment could not supplant the dialectic of "where all begins" for the future adult [32]. The stakes were such that the dynamic of equitable development for all children has reduced resignation in the face of the delay accumulated in certain nations with regard to medical density and revealed the nobility of solidarity and collaboration which annihilates technological disparity for a moment; making possible the perspective of intra and external alignment of nations according to target 10 of sustainable development objectives. The relevance of transferring patients from one country to another-as an alternative to expand useful interventions for their recovery-is being proven by the response against SARS-Cov2 [33]. This is the path that was taken thanks to the humanitarian collaboration with the Pediatric Hospital Bambino Gesu in Rome; in the case of the craniopagus twins born in a country long deprived of development by armed conflicts. However, this collaboration-how noble it may be-should it be able to withstand the pitfalls linked to reception capacity, the constraints of the health economy and social inequalities? Both major and minor reparable anomalies are prevalent in 
countries with high mortality [34]. The idea is to move towards the creation of a world reference center focusing the efforts of nations on extremely complex but rare major anomalies and to continue the transfer of skills to raise the medical density with regard to reparable anomalies the most frequent.

\section{Conclusion}

The successful separation of total posterior craniopagus twins, where both twins emerged from viable surgery without neurological deficits historically remains a great rarity. It required collaboration, detailed planning, and extensive surgical management. The transfer's management showed up the challenges regarding the application of the first 1000 days concept with regard to the human capital related to the health system. One will not go without the other.

\section{Conflicts of Interest}

The authors declare no conflicts of interest regarding the publication of this paper.

\section{References}

[1] Spencer R. (2003) Conjoined Twins. Developmental Malformations and Clinical Implications. Johns Hopkins University Press, Baltimore, 476.

[2] Spitz, L. and Kiely, E.M. (2003) Conjoined Twins. JAMA, 289, 1307-1310. https://doi.org/10.1001/jama.289.10.1307

[3] Edmonds, L.D. and Layde, P.M. (1982) Conjoined Twins in the United States, 1970-1977. Teratology, 25, 301-308

[4] Lemire, R.J., Loeser, J.D., Leech, R.W. and Alvord, E.C. (1975) Normal and Abnormal Development of the Human Nervous System. Harper \& Row, 14, 231-309.

[5] Wilson, R.L., Cetrulo, C.L. and Shaub, M.S. (1976) The Prepartum Diagnosis of Conjoined Twins by the Use of Diagnostic Ultrasound. American Journal of $O b$ stetrics and Gynecology, 126, 737. https://doi.org/10.1016/0002-9378(76)90536-6

[6] Quarello, E. and Ville, Y. (2005) Imagerie des grossesses gémellaires. Sauramps Medical, Montpellier, 74-83.

[7] Usta, I.M. and Awwad, J.T. (2000) Un diagnostic positif faux des jumeaux unis dans une grossesse de triplet: Pièges de diagnostic prénatal ultrasonographic de premier trimestre. Prenatal Diagnosis, 20, 169-170. https://doi.org/10.1002/(SICI)1097-0223(200002)20:2<169::AID-PD768>3.0.CO;2-C

[8] Body, G., Perrotin, F., Guichet, A., Paillet, C. and Descamps, P. (2001) La pratique du diagnostic prenatal. Masson, Paris, 227-235.

[9] Barth, R.A. and Crowe, H.C. (2000) Ultrasound Evaluation of Multifetal Gestations. In: Callen, P.W., Ed., Ultrasonography in Obstetrics and Gynecology, 4th Edition, Saunders, Philadelphie, 171-205.

[10] Konan Blé, R., Séni, K., Adjoussou, S., Quenum, G., Akaffou, E. and Koné, M. (2008) Jumeaux Conjoints Craniopages: Difficultés de prise en charge en milieu africain. Gynecologie, Obstetrique \& Fertilite, 36, 56-59. https://doi.org/10.1016/j.gyobfe.2007.08.027

[11] Marras, C.E., Lucia, C., Ilaria, P., Sergio, P., Mario, Z., Pietro, B., Enrio, C., Tomà, P., Alberto, V., Federico, V., Inserra, A. and Raponi, M. (2020) Traitement 
chirurgical du craniopagus: Expérience de l'hôpital Pédiatrique Bambino GESU de Rome. Session visioconférence du 3ème congrès de la Société Centrafricaine de Gynécologie-Obstétrique et 2ème congrès de la Société Centrafricaine de Pédiatrie, 27.

[12] Vaughn, T.C. and Powell, L.C. (1979) La gestion obstétrique des jumeaux unis. $O b$ stetrics Gynecology, 53, 67-72.

[13] Descamps, P. (2001) La pratique du diagnostic prénatal. Masson, Paris, 227-235.

[14] Mian, A., Gabra, N.I., Sharma, T., Topale, N., Gielecki, J., Tubbs, R.S. and Loukas, M. (2017) Jumeaux unis: De la conception à la séparation, une revue. Clinical Anatomy, 30, 385-396. https://doi.org/10.1002/ca.22839

[15] Mutchinick, O.M. (2011) Conjoined Twins: A Worldwide Collaborative Epidemiological Study. American Journal of Medical Genetics Part C: Seminars in Medical Genetics, 157, 274-287. https://doi.org/10.1002/ajmg.c.30321

[16] Spencer, R. (2000) Theoretical and Analytical Embryology of Conjoined Twins: Part I: Embryogenesis. Clinical Anatomy, 13, 36-53. https://doi.org/10.1002/(SICI)1098-2353(2000)13:1<36::AID-CA5>3.0.CO;2-3

[17] Boer, L.L., Schepens-Franke, A.N. and Oostra, R.J. (2019) Two is a Crowd: On the Enigmatic Etiopathogenesis of Conjoined Twinning. Clinical Anatomy, 32, 722-741. https://doi.org/10.1002/ca.23387

[18] Stone, J.L. and Goodrich, J.T. (2006) The Craniopagus Malformation: Classification and Implications for Surgical Separation. Brain, 129, 1084-1095.

https://doi.org/10.1093/brain/awl065

[19] Romero, R., Pilu, G., Jeanty, P., Ghidini, A. and Hobbins, J.C. (1988) Prenatal Diagnosis of Congenital Anomalies. Appleton and Lange, Norwalk.

[20] Hill, L.M. (1997) The Sonographic Detection of Early First-Trimester Conjoined Twins. Prenatal Diagnosis, 17, 961-963. https://doi.org/10.1002/(SICI)1097-0223(199710)17:10<961::AID-PD158>3.0.CO;2$\underline{Z}$

[21] Broussin, B. (2000) Les jumeaux conjoints: Diagnostic anténatal. Journal de Pédiatrie et de Puériculture, 13, 218-224. https://doi.org/10.1016/S0987-7983(00)80086-9

[22] Attar, I., Chaara, H., Jayi, S., Fdili Alaoui, F. and Melhouf, A. (2021) Grossesse gémellaire avec siamois parapages dicéphaliques diagnostiquée au $2^{\text {ème }}$ trimestre: à propos d'un cas et revue de la littérature. International Journal of Medical Reviews and Case Reports, 5, 23-27. https://doi.org/10.5455/IJMRCR.siamois-parapages

[23] Afzal, A.R. and Montero, F.J. (2020) Conjoined Twins. StatPearls Publishing, Treasure Island.

[24] Mackenzie, T.C., Crombleholme, T.M., Johnson, M.P., Schnaufer, L., Flake, A.W., Hedrick, H.L., et al. (2002) The Natural History of Prenatally Diagnosed Conjoined Twins. Journal of Pediatric Surgery, 37, 303-309. https://doi.org/10.1053/jpsu.2002.30830

[25] Al Rabeeah, A. (2006) Conjoined Twins-Past, Present and Future. Journal of Pediatric Surgery, 41, 1000-1004. https://doi.org/10.1016/j.jpedsurg.2005.12.045

[26] Hovorakova, M., Peterkova, R., Likovsky, Z. and Peterka, M. (2008) A Case of Conjoined Twin's Cephalothoracopagus Janiceps Disymmetros. Reproductive Toxicology, 26, 178-182. https://doi.org/10.1016/j.reprotox.2008.06.005

[27] Winston, K.R. (1987) Craniopagi: Anatomical Characteristics and Classification. Neurosurgery, 21, 769-781. https://doi.org/10.1227/00006123-198712000-00001

[28] Voris, H.C. (1963) Cranioplasty in a Craniopagus Twin. Journal of Neurosurgery, 
20, 145-147. https://doi.org/10.3171/jns.1963.20.2.0145

[29] Voris, H.C., Slaughter, W.B., Christian, J.R. and Cayia, E.R. (1957) Successful Separation of Craniopagus Twins. Journal of Neurosurgery, 14, 548-560. https://doi.org/10.3171/jns.1957.14.5.0548

[30] Campbell, S. (2004) Separation of Craniopagus Twins: The Brisbane Experience. Child's Nervous System, 20, 601-606. https://doi.org/10.1007/s00381-004-0990-7

[31] Alana, T., Karen, J., and Placencia, F.X. (2018) An Ethically-Justifiable, Practical Approach to Decision-Making Surrounding Conjoined-Twin Separation. Seminars in Perinatology, 42, 381-385. https://doi.org/10.1053/j.semperi.2018.07.016

[32] Roegiers, L. (2021) Regard critique sur le Rapport "Les 1000 premiers jours. Là où tout commence". Périnatalité, 13, 58-62.

[33] Châtelus, C. (2020) Ma guerre du COVID. Journal d'une urgentiste alsacienne dans la crise du coronavirus. Des Equateurs, Paris, 130.

[34] Azria, E. (2015) Inégalités sociales en santé périnatale. Archives de Pédiatrie, 22, 1078-1085. https://doi.org/10.1016/j.arcped.2015.07.006 